\title{
P01.32. Can homeopathic verum and placebo globules be distinguished by UV spectroscopy?
}

\author{
U Wolf*, S Klein \\ From International Research Congress on Integrative Medicine and Health 2012 \\ Portland, Oregon, USA. 15-18 May 2012
}

\section{Purpose}

Homeopathic preparations are used in homeopathy and anthroposophically extended medicine. Previous studies described differences in UV transmission between homeopathic preparations of $\mathrm{CuSO}_{4}$ and controls. The aim of the present study was to investigate whether statistically significant differences can be found between homeopathic verum and placebo globules by UV spectroscopy.

\section{Methods}

Verum (aconitum 30c, calcium carbonate/quercus e cortice) and placebo globules used in two previous clinical trials were dissolved in distilled water at $10 \mathrm{mg} / \mathrm{ml} \mathrm{20-23}$ hours prior to the measurements. Absorbance was measured at 190 - 340nm with a Shimadzu UV-1800 double beam spectrophotometer. Duplicates of each sample were measured in a randomized order 4 times on each of the 5 measurement days. To correct for differences between measurement days, average absorbance of all samples on one day was deduced from absorbance of the individual samples. The Kruskal-Wallis test was used to determine group differences between the samples, and finally the coding of the samples was revealed.

\section{Results}

First analysis showed significant differences $(\mathrm{p} \leq 0.05)$ in average UV absorbance at $200-290 \mathrm{~nm}$ between the samples and a tendency of a correlation $(\mathrm{p} \leq 0.1)$ between absorbance and globule weight. More results will be presented at the conference.

\section{Conclusion}

Since the absorbance of the samples at the wavelengths between 200 and $290 \mathrm{~nm}$ was small, a number of aspects

University of Bern, Institute of Complementary Medicine KIKOM, Bern, Switzerland had to be considered and should be corrected for if they are present when performing UV spectroscopy on homeopathic globules: (1) Exact weighing of the globules; (2) Measurement error of the spectrophotometer at small absorbances; (3) Drift of the spectrophotometer during a measurement day; (4) Differences between measurement days.

The question remains what caused the differences in absorbance found in these experiments; the use of the original material for the production of the verum globules, differences in the production of verum and placebo globules, or other context factors.

Published: 12 June 2012

doi:10.1186/1472-6882-12-S1-P32

Cite this article as: Wolf and Klein: P01.32. Can homeopathic verum and placebo globules be distinguished by UV spectroscopy? BMC Complementary and Alternative Medicine 2012 12(Suppl 1):P32.
Submit your next manuscript to BioMed Central and take full advantage of:

- Convenient online submission

- Thorough peer review

- No space constraints or color figure charges

- Immediate publication on acceptance

- Inclusion in PubMed, CAS, Scopus and Google Scholar

- Research which is freely available for redistribution
C Biomed Central 